\title{
PENGELOLAAN PERSEDIAAN JASA: SUATU CONTOH APLIKASI PADA JASA RUMAH SAKIT
}

\author{
Cecep Hidayat \\ Management Department, School of Business Management, BINUS University \\ Jl K.H. Syahdan No 9 , Palmerah, Jakarta Barat 11480 \\ ceceph1267@binus.ac.id
}

\begin{abstract}
The services sector contribute more than 70\% of gross domestic product (GNP) almost all countries in the world, even the more advanced the countries are the more contribution the countries will give. Services inventory means that complementary service inventories, both human beings and machines, as well as goods and equipment that accompany delivery of services.Inventory models for services haven't been specific, but basically they are almost similar to the inventory model for the product in the form of goods. The hospital are the places of business that produce services, so that the logistic of hospital is not the logistics of goods distribution, but it is only about material goods inventory management and equipment needed to produce those services. The most aplicable inventory services for hospital are the ABC classification model.
\end{abstract}

Keywords: service inventory, inventory models, hospital services, ABC classification

\begin{abstract}
ABSTRAK
Sektor jasa merupakan sektor yang memberikan kontribusi lebih dari $70 \%$ produk domestik bruto (GNP) hampir seluruh negara di dunia ini, bahkan semakin maju suatu negara maka sektor jasanya pun semakin memberikan kontribusi yang semakin besar. Persedian jasa maksudnya adalah persedian pelengkap jasa itu sendiri, baik berupa manusia sebagai mahluk hidup maupun mesin-mesin, barang-barang atau perlengkapan lainnya yang menyertai penghantaran sebuah layanan atau jasa. Model-model persedian untuk jasa belum ada yang spesifik, akan tetapi secara garis besar hampir sama dengan model persediaan untuk produk yang berupa barang. Rumah sakit merupakan suatu usaha yang melakukan produksi jasa sehingga logistik dalam rumah sakit bukan logistik pendistribusian barang, tetapi hanya menyangkut manajemen persediaan bahan barang serta peralatan yang dibutuhkan untuk memproduksi jasa tersebut. Model persedian jasa yang paling banyak diaplikasikan untuk sebuah rumah sakit adalah model klasifikasi ABC.
\end{abstract}

Kata kunci: persedian jasa, model persediaan, jasa rumah sakit, klasifikasi ABC 


\section{PENDAHULUAN}

Jasa meliputi seluruh kegiatan ekonomi yang menghasilkan keluaran (output) produk berupa barang atau hasil karya nonfisik/barang, yang pada umunnya dikonsumsi pada saat diproduksi dan dapat memberikan suatu nilai tambah. Seperti kita ketahui berdasarkan salah satu karakteristik jasa bahwa jasa tidak tidak terlepas dari penyedia jasa, baik itu berupa manusia maupun mesin/perlengkapan yang melekat pada jasa tersebut. Jasa adalah prestasi dari penyedia jasa itu sendiri, dimana bila tidak ada penyedia jasa, maka tidak akan muncul prestasi atau jasa tersebut. Dalam praktik ada bisnis jasa murni, produk barang murni, atau gabungan antara keduanya. Dalam dunia modern seperti sekarang ini hampir sebagian besar bisnis jasa khusunya perusahaan besar adalah bukan jasa murni, dalam arti ada produk yang berupa barang atau perlengkapan yang menyertai penghantaran jasa tersebut. Seperti halnya produk yang berupa barang (goods) dalam jasa juga dikenal persediaan atau inventori. Persedian jasa maksudnya adalah persedian pelengkap jasa itu sendiri, baik berupa manusia sebagai mahluk hidup maupun mesin-mesin, barang-barang atau perlengkapan lainnya yang menyertai penghantaran sebuah layanan atau jasa.

Pada dasarnya teori atau teknik persedian jasa itu sendiri tidak jauh berbeda dengan teori persedian untuk produk berupa barang. Dewasa ini penggunaan teknologi informasi memainkan peranan yang sangat penting dalam fungsi persediaan. Seperti halnya penggunaan barcode yang dapat dibaca oleh alat scanning untuk setiap item barang banyak digunakan untuk jasa-jasa ritel, bahkan meluas ke penggunaan jaringan komputer (internet) serta teknologi satelit untuk pengendalian persediaan secara global.

Sektor jasa merupakan sektor yang memberikan kontribusi lebih dari $70 \%$ produk domestik bruto (GNP) hampir seluruh negara di dunia ini, bahkan semakin maju suatu negara maka sektor jasanya pun semakin memberikan kontribusi yang semakin besar. Salah satu klasifikasi jasa adalah jasa personal (personal service). Salah satu contoh dari bentuk jasa personal tersebut tersebut adalah jasa pelayanan kesehatan dan medis sebuah rumah sakit, baik jasa rumah sakit umum ataupun rumah sakit untuk penderita-penderita penyakit tertentu. Seperti halnya sektor manufaktur sektor jasa pun tidak terlepas dari para penyedia jasa dan prasarana/infrastruktur yang melekat pada penghantaran jasa tersebut. Demikian halnya dengan jasa pelayanan medis sebuah rumah sakit memerlukan manajemen persediaan jasa untuk pencapaian tujuan dan pengarahan proses operasionalisasinya. Rumah sakit merupakan suatu usaha yang melakukan produksi jasa sehingga logistik dalam rumah sakit bukan logistik pendistribusian barang, tetapi hanya menyangkut manajemen persediaan bahan barang serta peralatan yang dibutuhkan untuk memproduksi jasa tersebut. Banyak sekali persedian barang-barang sebagai perlengkapan infrastruktur lembaga rumah sakit. Demikian pula halnya dengan tenaga manusia sebagai tenaga medik (dokter, perawat) dan non medis merupakan tenaga penyedia jasa utama yang memerlukan manajemen persediaan yang optimal dalam kegiatan operasi lembagalembaga rumah sakit. Berbeda dengan sektor jasa lainnya, jasa pelayanan kesehatan tidak memiliki orientasi utama pada profit akan tetapi lebih kepada tujuan sosial. Disamping itu juga lebih pada aspek efektivitas disbanding dengan efisiensi. Rumah sakit merupakan suatu usaha yang melakukan produksi jasa sehingga logistik dalam rumah sakit bukan logistik pendistribusian barang, tetapi hanya menyangkut manajemen persediaan bahan-bahan serta peralatan yang dibutuhkan untuk memproduksi jasa tersebut.

Jasa pelayanan kesehatan merupakan jasa yang bersifat kompleks karena bersifat padat karya dan padat modal. Artinya, dibutuhkan banyak tenaga kerja yang memiliki keahlian khusus dalam bidang kesehatan dan padat modal karena membutuhkan infrastruktur (peralatan) yang lengkap dan harganya cukup mahal. Dewasa ini jasa pelayanan kesehatan memegang peranan vital dalam mengembangkan dan meningkatkan kualitas sumber daya manusia. Keberhasilan jasa kesehatan ditentukan dalam memberikan pelayanan yang berkualitas kepada para pengguna jasa kesehatan tersebut (pasien). Sama halnya seperti permintaan produk berupa barang, permintaan akan jasa 
pelayanan kesehatan khususnya di Indonesia di antara berbagai lembaga pelayanan kesehatan mengalami pola yang beragam. Walaupun tingkat kesadaran hidup sehat semakin meningkat, akan tetapi pola permintaan untuk satu lembaga penyedia layanan kesehatan berbeda-beda. Hal tersebut tentunya seperti halnya produk barang tergantung banyak faktor seperti kualitas pelayanan lembaga yang bersangkutan, disain dan rancangan pelayanan konsumen, pengemasan, promosi dan aspek-aspek lainnya.

Jasa layanan kesehatan tidak dapat dipisahkan dari sumbernya, yaitu lembaga (rumah sakit) yang menyediakan jasa tersebut. Artinya, jasa pelayanan kesehatan dihasilkan dan dikonsumsi secara serempak (simultan) pada waktu yang sama. Jika seorang pasien membeli jasa maka akan berhadapan langsung dengan penyedia jasa pelayanan kesehatan seperti tenaga administratif, dokter, perawat dan tenaga medis lainnya. Dengan demikian, jasa lebih diutamakan penjualannya secara langsung dengan skala operasi yang terbatas. Oleh karena itu, lembaga pelayanan kesehatan dapat menggunakan strategi bekerja dalam kelompok yang lebih besar, bekerja lebih cepat, atau melatih para penyaji jasa agar mereka mampu membina kepercayaan pelanggannya.

\section{METODE}

Metode penelitian yang digunakan dalam penulisan makalah ini adalah kajian literatur yang berupaya membahas konsep dan teori-teori yang digunakan dalam model persediaan jasa. Adapun referensi utama yang dijadikan bahan analisis adalah berupa buku teks yang membahas manajemen jasa dan jurnal-jurnal utama yang terpilih yang berkaitan dengan manajemen jasa, khususnya pengelolaan persediaan jasa (managing service inventory). Jasa pelayanan rumah sakit merupakan jasa yang dipilih untuk pembahasan aplikasi teori dan model persedian jasa tersebut

\section{Tinjauan Pustaka}

Dalam bagian ini akan coba dikaji beberapa teori utama tentang manajemen persedian, pertama teori tentang jasa itu sendiri dan kedua yaitu teori-teori yang menjawab tiga pertanyaan mendasar dalam manajemen persediaan, yaitu teori tentang jumlah pemesanan yang optimal, kapan waktu pemesanan, dan berapa banyak persediaan yang harus dipertahankan.

\section{Manajemen Persediaan Jasa (Service Inventory)}

Pada dasarnya persedian tidak boleh lebih dan tidak boleh kurang, lebih merupakan biaya dan kurang juga adalah biaya. Bila belebihan maka akan menimbulkan biaya-biaya seperti biaya kerusakan, pemeliharaan, pencurian, dan biaya lainnya. Bila persediaan kurang akan menimbulkan biaya seperti biaya kehilangan kesempatan dan biaya kehilangan pelanggan. Jadi manajemen persediaan pada dasarnya bagaimana mengelola persediaan pada tingkat yang optimal. Meskipun salah satu sifat jasa itu sendiri adalah tidak berwujud akan tetapi jasa itu sendiri tidak terlepas dari penyedia jasa dan barang pelengkap yang menyertai penghantaran jasa itu sendiri yang sifatnya berwujud (tangible). Pengelolaan fasilitas komponen barang sebagai paket pelengkap jasa mencakup biaya trade off, pelayanan pelanggan, dan sistem informasi. Menurut Fitzsimmons, pada dasarnya manajemen persediaan adalah pertanyaan yang memusatkan perhatian pada kuantitas pemesanan, dan model kuantitas pemesanan yang dikembangkan untuk beragam aplikasi persediaan. Kapan menempatkan suatu pesanan (disebut reorder point) adalah pusat pertanyaan lain manajemen persediaan (Fitzsimmons, 2011:479).

\section{Peranaan Persediaan dalam Jasa}

Adapun peranan dari persedian dalam jasa tersebut adalah sebagai berikut. Persediaan Perangkai (decoupling Inventories), dimana fungsi ini berkaitan dengan bagaimana dua tipe rangkaian 
aliran informasi dan produk fisik bekerja dari hulu sampai ke hilir. Kedua aliran tersebut berbeda dalam hal titik asalnya, dimana produk fisik sumber utamanya (hulu) adalah pabrik dan aliran informasi sumber dasarnya adalah konsumen. Jadi pada dasarnya baik informasi maupun aliran fisik merupakan permintaan turunan dari titik asalnya. Secara lebih terperinci kedua macam aliran tersebut (informasi dan produk fisik) dapat dilihat dalam gambar1.

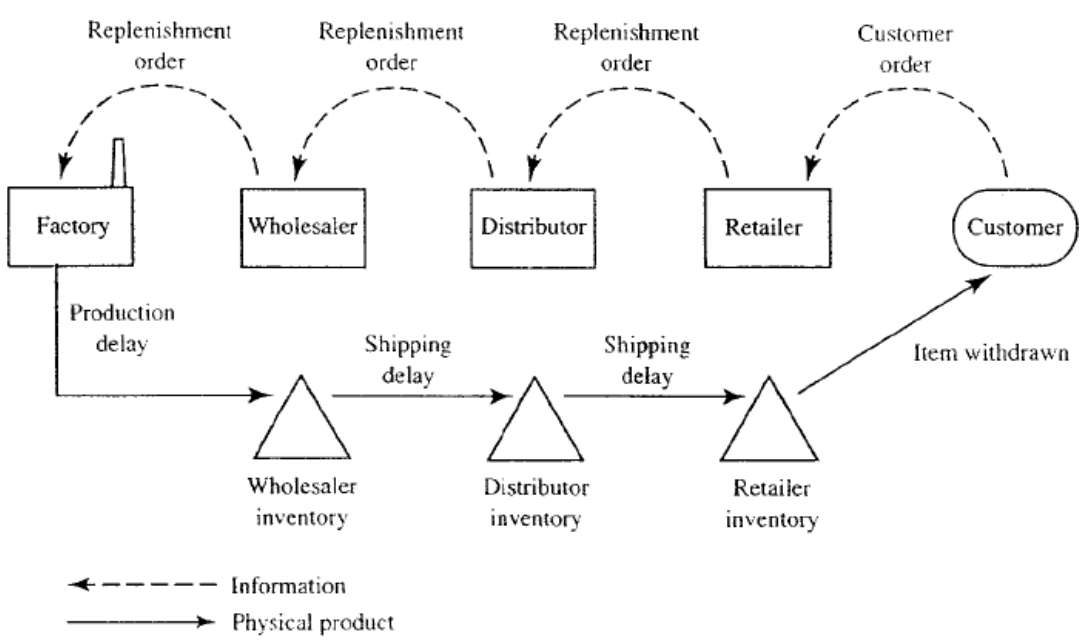

Gambar 1 Sistem Distribusi Informasi dan Barang Sumber: Fitzsimmon, 2011:479

Persediaan Musiman, dimana beberapa jasa berkaitan dengan permintan musiman yang signifikan. Seperti halnya jasa pendidikan, jasa parawisata, jasa perhotelan dan lain-lain yang pola permintaannya musiman. Dengan demikian sstem dan model persediaanya pun menyesuaikan dengan pola musiman tersebut. Beberapa layanan melibatkan tuntutan musiman yang signifikan. Persedian Spekulatif; sebuah layanan yang mengantisipasi peningkatan yang signifikan dalam biaya yang baik yang berhubungan, mungkin akan lebih ekonomis untuk mengumpulkan dan memelihara persediaan yang besar dengan harga saat ini bukan untuk mengganti persediaan setelah meningkat, strategi mempertahankan persediaan spekulatif dikenal sebagai "pembelian maju”.

Persediaan.Siklus, dimana merujuk pada variasi normal pada tingkat persediaan. Dengan kata lain, tingkat persediaan dalam inventori berada pada titik tertinggi hanya setelah pesanan diterima, dan menurun ke titik terendah sebelum perintah baru diterima.Persediaan dalam perjalanan (In-Transit Inventory). Istilah inventori dalam perjalanan digunakan untuk persediaan yang telah diperintahkan tetapi belum tiba. Persediaan pengaman (safety inventory), dimana suatu pelayanan yang efektif mempertahankan persediaan yang diharapkan akan memenuhi permintaan. Layanan beroperasi dalam lingkungan yang dinamis, namun, yang jelas bahwa ketidakpastian dalam waktu pengisian dan permintaan selalu ada. Untuk mengatasi fluktuasi yang tidak diharapkan, banyak layanan mempertahankan persediaan yang melebihi persediaan disimpan untuk memenuhi permintaan yang diharapkan. Kelebihan persediaan ini disebut sebagai safety stock.

Pada dasarnya manajemen persediaan berkaitan dengan tiga pertanyaan dasar, yaitu (1) jumlah seharusnya kuantitas pesanan, (2) waktu pesanan ditempatkan (disebut titik pemesanan kembali), dan (3) jumlah banyak persedian pengaman (safety stock) harus dipertahankan. 


\section{Karakteristik Sistem Persediaan}

Untuk merancang, melaksanakan, dan mengelola suatu sistem inventaris kita harus mempertimbangkan karakteristik dari persediaan yang akan disimpan dan juga harus memahami atribut-atribut dari keragaman sistem inventori yang tersedia. Adapun karakteristik tersebut antara lain sebagai berikut.

Tipe permintaan konsumen; terdapat dua tipe utama permintaan yaitu permintaan independent dan permintaan dependent. Permintaan independen adalah permintaan yang jumlah permintaannya tidak tergantung pada permintaan barang lain, seperti misalnya permintaan barang kelontong (convenience) umumnya bersifat independen. Permintaan dependen adalah permintaan yang kuantitasnya tergantung permintaan barang lain yang menjadi komplementernya, misalnya permintaan sebuah software tergantung dari permintaan hardware, permintaan velk dan ban mobil tergantung jumlah permintaan mobil itu sendiri.

Perencanaan Horison Waktu (time horizon). Manajemen harus mempertimbangkan apakah akan inventarisasi persediaan dari item tertentu tanpa batas waktu atau jika kebutuhan untuk item bersifat sementara. Sebagai contoh, sebuah rumah sakit selalu membutuhkan tangki oksigen, tetapi pengecer pakaian olahraga tidak perlu kehabisan pasokan kaus olahraga.

Pengisian waktu tunggu (lead time) Pengisian waktu tunggu memiliki dampak yang jelas pada kebutuhan persediaan. Jika kita mengharapkan waktu yang relatif lama antara menempatkan pesanan dan menerima, kita harus membawa persediaan lebih besar daripada jika kita mengantisipasi waktu tunggu yang pendek, terutama ketika item penting yang terlibat. Jika waktu tunggu adalah stokastik dengan distribusi probabilitas yang terkait. kita mungkin dapat menggunakan informasi ini untuk menentukan kebutuhan persediaan selama lead time.

Hambatan-hambatan dan biaya-biaya persediaan yang relevan. Beberapa kendala dianggap mudah, sebagai contoh, ruang penyimpanan yang tersedia menentukan jumlah maksimum barang yang dapat disimpan, dan "kehidupan rak" dari barang yang baik juga dapat membatasi jumlah item yang mudah rusak yang dapat diselenggarakan di persediaan. Kendala lain yang lebih kompleks, seperti biaya pemeliharaan inventaris, dan ada biaya yang jelas seperti belanja modal untuk fasilitas penyimpanan, baik itu gudang atau refigerator. Produk diselenggarakan di persediaan juga merupakan belanja modal (yaitu, mereka mewakili suatu biaya kesempatan dari modal). Biaya lainnya termasuk personalia dan pemeliharaan yang diperlukan untuk mengelola persediaan sebagai "terduga" seperti asuransi dan pajak atas aktiva yang diinventarisasi.

\section{Biaya-biaya yang Relevan dalam Sistem Persediaan}

Biaya-biaya utama yang relevan dalam sistem persedian antara lain adalah biaya pemesanan (ordering cost), biaya penerimaan dan pemeriksaan (receiveing and inspection cost), biaya penanganan atau biaya pengangkutan (holding or carrying cost), dan biaya kekurangan bahan (shortage cost).

\section{Jumlah Pemesanan yang Ekonomis (EOQ)}

Persediaan diadakan untuk menghindari gangguan, waktu, dan biaya kelengkapan lain-lain yang konstan. Beberapa keseimbangan (trade-off) atau kompromi diperlukan dalam menentukan berapa banyak persediaan untuk menampung, dan karena itu berapa banyak persediaan untuk dipesan. Ada biaya menyimpan persediaan dan ada biaya pemesanan ulang persediaan dan kedua biaya harus seimbang. 
Jumlah pemesanan yang ekonomis (EOQ) adalah tingkat persediaan yang meminimalkan total biaya menyimpan persediaan dan biaya pemesanan. Ini adalah salah satu model penjadwalan produksi klasik tertua.Tujuan dari model EOQ adalah untuk meminimalkan total biaya persediaan. Biaya penting adalah biaya pemesanan, biaya penempatan order, dan biaya membawa atau memegang unit persediaan dalam persediaan. Semua biaya lain seperti, misalnya, biaya pembelian persediaan itu sendiri, yang konstan dan karena itu tidak relevan dengan model. Gambar 2 memperlihatkan bagaimana tingkat persediaan dalam model EOQ, dimana sumbu vertikal menggambarkan jumlah unit persediaan di tangan dan sumbu horizontal menggambarkan waktu yang diperlukan untuk sejumlah pemesanan. Dalam model tersebut kekurangan persediaan tidak direncanakan artinya bahwa pemesanan (reorder point) dilakukan ketika persedian mencapai titik nol. Jika kekurangan persedian direncanakan maka sebelum persediaan habis pemesanan dilakukan, sehingga ketika persediaan habis barang yang dipesan sudah diterima. Gambar 3 memperlihatkan tingkat persediaan jika kekurangan direncanakan dalam suatu model EOQ.

Model EOQ adalah suatu rumusan untuk menentukan kuantitas pesanan yang akan meminimumkan biaya persediaan. Dalam dunia nyata, pada umumnya perusahaan menggunakan lebih dari satu unit item dalam persediaannya, sangat jarang perusahaan yang menggunakan satu unit item saja. Model EOQ dasar ini hanya berlaku jika memenuhi beberapa asumsi sebagai berikut : (1) Hanya satu produk yang tercakup, (2) Jumlah permintaan tahunan diketahui, (3) Permintaan terjadi sepanjang tahun, (3) waktu tunggu (lead time) tidak bervariasi, (4) Setiap pesanan diterima dalam satu waktu (4) tidak ada potongan kuantitas (discount quantity). Asumsi tersebut sekaligus menjadi kelemahan model EOQ itu sendiri, karena dalam praktek dimana lingkungan, situasi dan kondisi sangat berubah dengan cepat memenuhi satu asumsipun sangat sulit, apalagi dua, tiga atau seluruh asumsi dapat terpenuhi.

Gambar 2 Tingkat Persedian untuk Model EOQ

Sumber: Stevenson, 2009

\section{Titik Pemesanan Kembali (ROP) dan Persedian Pengaman (Safety Stock)}

Titik pemesanan kembali (Reorder Point) adalah tingkat persediaan paling rendah saat pesanan harus dibuat dengan pemasok untuk memastikan persediaan barang masih ada untuk digunakan. Konsep ini sering salah diartikan karena titik pemesanan kembali diartikan seolah-olah tidak boleh ada pemesanan kembali sebelum titik ini dicapai. Padahal sebenarnya perusahaan seharusnya memesan kembali barang yang dibutuhkannya setiap saat jumlah pesanan ekonomis memungkinkanya. Persediaan Pengaman (safety stock) minimum yang harus selalu ada dan selalu siap tersedia didalam gudang yang dimaksudkan untuk mengantisipasi. Dalam gambar 3 dan gambar 4 dijelaskan secara grafis konsep titik pemesanan kembali dan persediaan pengaman. 


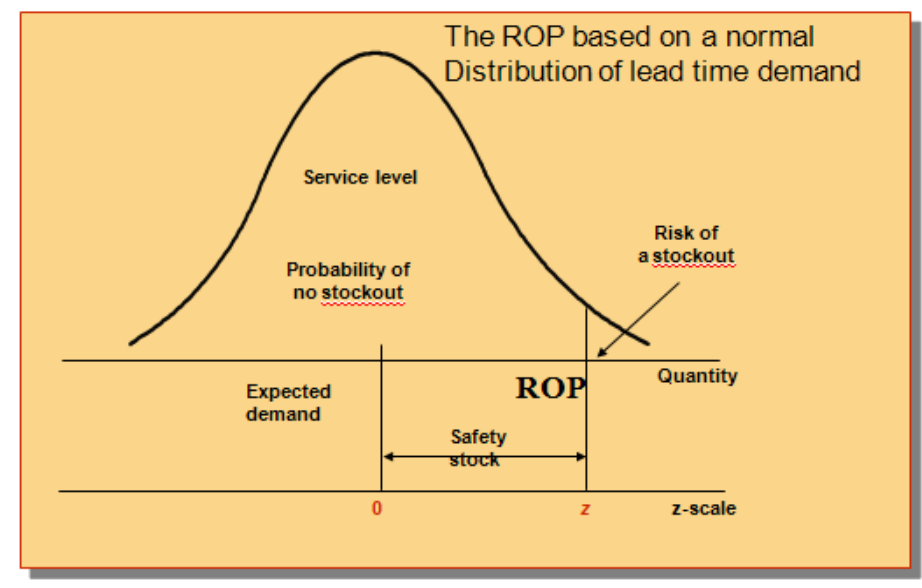

Gambar 3 Titik Pemesanan Kembali (Reorder Point) Sumber: Stevenson, 2009

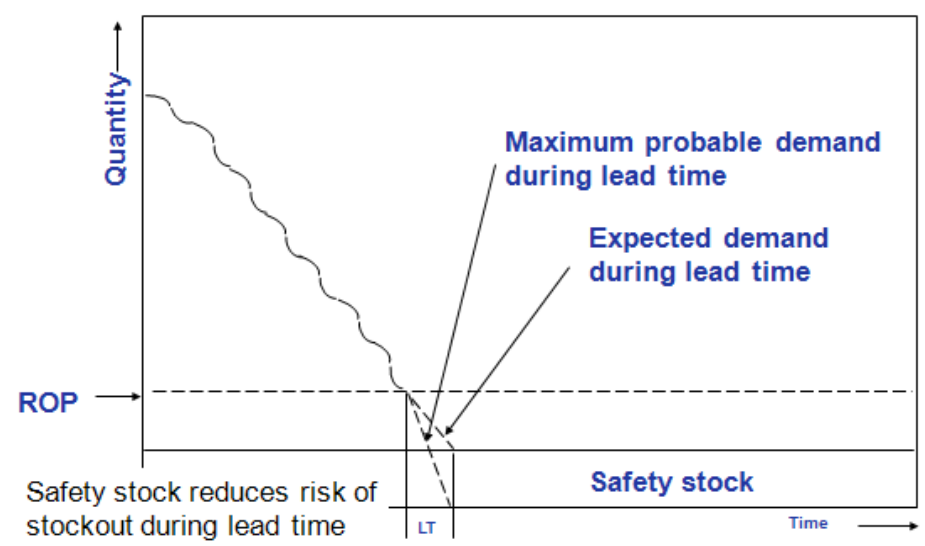

Gambar 4 Persediaan Pengaman (Safety Stock)

Sumber: Stevenson, 2009

Berkaitan dengan jumlah pesanan (order), menurut Feng, Markus; Grace, \& Yao (2002:144) terdapat dua katagori operasi pesanan yaitu system Configure-To -Order (CTO) dan Assembly-ToOrder (ATO). Sistem CTO adalah suatu bentuk campuran (hybrid) dari make-to -stock dan operasi make-to-order.Mereka mengembangkan sebuah model optimasi non linear dengan multiple constrains. Model CTO menjadi model operasional yang ideal yang memberikan customization massal dan waktu tanggapan yang cepat dalam memenuhi pesanan. Disamping itu juga mengkuantifikasi keseimbangan persediaan jasa dalam lingkungan CTO.

Masih berkaitan dengan jumlah pemesanan, penelitian yang dilakukan oleh Katok. E., Thomas D., \& Davis, A (2008:623) mengemukakan bahwa luasnya review bahasan periode dan hubungan antara order-up-to-level yang optimal denganluasnya periode review sangat kompleks. Jika pemasok memaksimalkan profit, terdapat situasi dimana periode review yang lebih pendek akan lebih disukai. Disamping itu juga dari hasil penelitiannya ditemukan hubungan bahwa bonus yang sangat tinggi akan mempengaruhi pesanan yang tinggi. 


\section{Biaya Tahunan untuk Model Diskon Kuantitas}

Model EOQ sebelumnya (dasar) mengasumsikan bahwa tidak ada potongan harga untuk pembelian dalam jumlah tertentu. Model EOQ dengan potongan kuantitas dapat mendorong pelanggan membeli dalam ukuran Batch penuh, lebih jauh dapat menghemat biaya transportasi dan biaya bongkar muat. Akan tetapi Trade off terjadi manakala pembelian dilakukan dalam jumlah besar, yaitu di satu sisi menghemat biaya pembelian dan di sisi lain meningkatkan biaya pemeliharaan. Dalam rangka mengatasi tersebut maka rumus untuk biaya total minimum adalah sebagai berikut.

$$
\begin{aligned}
\text { Total Cost } & =\text { Purchase Cost }+ \text { Ordering Cost }+ \text { Holding Cost } \\
T C_{q d} & =C D+S(D / Q)+I(C Q / 2)
\end{aligned}
$$

Dimana $\mathrm{C}=$ unit cost of item in dolla

$$
\text { = annual inventory holding cost }
$$

Disamping mode EOQ dasar yang telah dibahas sebenarnya masih terdapat beberapa teori EOQ sebagai pengembangan teori EOQ dasar tersebut. Adapun teori EOQ lainnya adalah seperti model, model dynamic EOQ, model POQ, dan model-model lainnya. Seperti halnya model EOQ dasar model tersebut pun memiliki sejumlah asumsi yang harus dipenuhi.

\section{Model Persediaan dengan Kekurangan Terencana (planned shortage)}

Jika konsumen dapat mentolerir kehabisan persediaan, system persediaan dengan kekurangan terencana adalah memungkinkan. Sebagai contoh sebuah toko ban mungkin tidak memiliki persediaan semua ukuran ban high performance, diketahui bahwa konsumen mau menunggu satu atau dua hari jika ban khusus tidak ada dalam persediaan. Dengan menggunakan pertukaran data elektronik (EDI) dan delivery yang dapat diperkirakan dari pemasok, suatu strategi minimal inventory stocking dapat diterapkan.

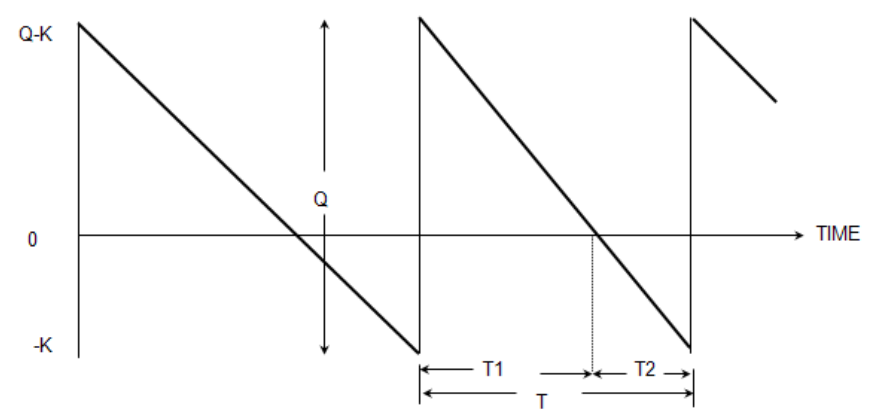

Gambar 5 Tingkat Persedian untuk Model Keurangan Persediaan yang Terencana Sumber: Fitzsimmons \& Fitzsimmons (2011:488)

Adapun formula untuk model gambar kekurangan persedian yang terencana tersebut adalah ssebagai berikut.

$$
\begin{aligned}
& T C_{b}=S \frac{D}{Q}+H \frac{(Q-K)^{2}}{2 Q}+B \frac{K^{2}}{2 Q} \\
& Q^{*}=\sqrt{\frac{2 D S}{H}\left(\frac{H+B}{B}\right)} \\
& K^{*}=Q^{*}\left(\frac{H}{H+B}\right)
\end{aligned}
$$




\section{Manajemen Persediaan dalam Kondisi Ketidakpastian}

Model EOQ sederhana tidak mempertimbangkan ketidakpastian dalam tingkat permintaan atau penambahan waktu tunggu. Setiap kali pesanan ditempatkan, ketidakpastian menimbulkan resiko kehabisan persediaan terjadi sebelum penambahan pesanan tiba. Untuk mengurangi resiko kehabisan persediaan selama waktu tersebut, persediaan tambahan dapat diadakan lebih dari permintaan yang diharapkan selama waktu tunggu. Istilah kunci untuk manajemen persediaan di bawah ketidakpastian adalah konsep service level yang didefinisikan sebagai prosentase permintaan yang terjadi selama waktu tunggu yang dapat dipenuhi dari persediaan. Adapu rumus-rumus yang berkaitan dengan persediaan di bawah kondisi ketidakpastian tersebut adalah sebagai berikut.

$$
\text { Permintaan selama waktu tunggu: } \operatorname{Mean}\left(d_{L}\right)=\mu(L T) \quad \text { Std.Dev. }\left(\sigma_{L}\right)=\sigma \sqrt{L T}
$$

$$
\text { Safety Stock Level: } \quad S S=z_{r} \sigma \sqrt{L T}
$$

Titik Pemesanan Kembali: $\quad R O P=S S+d_{L}$

\section{Sistem Pengendalian Persediaan}

Beberapa sistem pengendalian persedian digunakan dalam praktek. System-sistem persedian tersebut berbeda dalam metode penentuan jumlah pesanan dan kapan suatu penambahan pesanan dibuat. Secara umum ada dua system pengendalian persediaan yaitu: sistem review berkelanjutan (continuous review system) dan sistem review periodik (periodic review system).

\section{Klasifikasi ABC dalam Persediaan}

Klasifikasi ABC adalah salah satu cara pengendalian persediaan dengan menggunakan analisis nilai persediaan. Klasifikasi ABC ini merupakan aplikasi persediaan yang menggunakan prinsip Pareto dimana intinya adalah fokus pengendalian persediaan pada item (jenis) persediaan yang bernilai tinggi (critical) dari pada yang bernilai rendah (trivial). Klasifikasi ABC membagi persediaan menjadi tiga kelas berdasarkan atas nilai persediaan sehingga dapat diketahui item mana yang harus mendapat perhatian lebih dibandingkan dengan item yang lainnya. Sedangkan nilai yang dimaksud dalam klasifikasi ABC ini bukanlah harga persediaan per unit, melainkan volume persediaan yang dibutuhkan dalam satu periode dikalikan dengan harga per unitnya. Adapun, kriteria-kriteria dalam klasifikasi ABC adalah sebagai berikut.

Kelas A - Persediaan ini memiliki nilai volume tahunan rupiah yang tinggi. Kelas ini memiliki sekitar $70 \%$ dari dari total nilai persediaan meskipun jumlahnya sedikit (sekitar 20\%). Sehingga harus mendapat perhatian yang sangat serius karena akan berdampak pada biaya yang tinggi.

Kelas B - Persediaan ini mempunyai nilai volume tahunan rupiah yang menengah. Kelompok ini merepresentasikan sekitar 20\% dari total nilai persediaan dan memiliki jumlah item sekitar 30\%. Sehingga diperlukan teknik pengendalian persediaan yang moderat.

Kelas C - Persediaan ini memiliki nilai volume tahunan rupiah sekitar 10\% dari total nilai persediaan. Akan tetapi memiliki jumlah item persediaan sekitar 50\%. Dengan demikian hanya diperlukan teknik pengendalian yang sederhana.

Penggambaran secara grafis klasifikasi ABC dalam persediaan tersebut adalah seperti terlihat dalam gambar 6. 


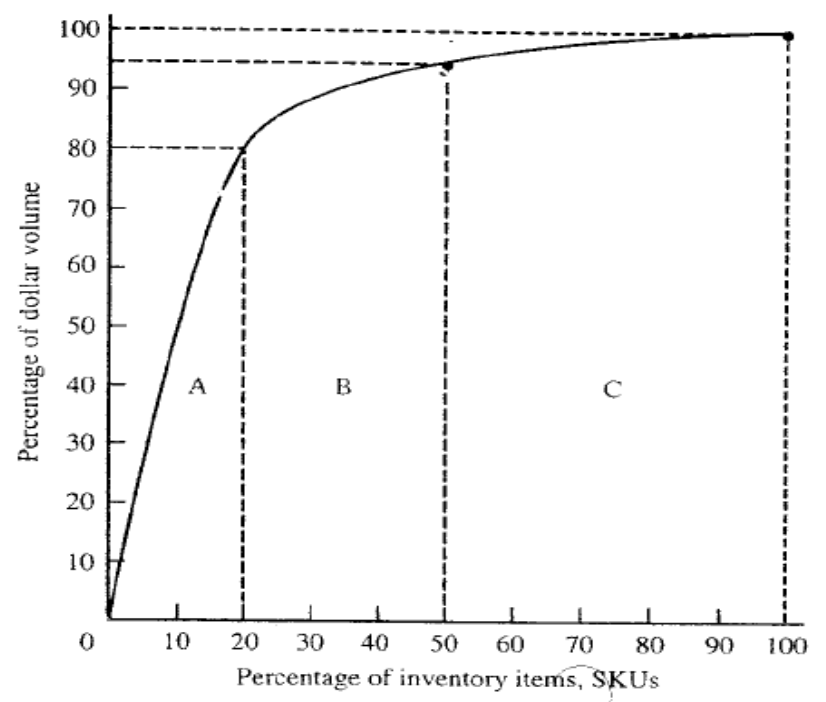

Gambar 6 Klasifikasi ABC untuk Item Persediaan Sumber: Fitzsimmon (2011:494)

Menurut Chopra and Lariviere (2005;4) dalam bisnis jasa pekerjaan dapat dilakukan dan disimpan dalam mengantisipasi permintaan. Dengan bijaksana memilih jenis persediaan untuk ditangani, perusahaan dapat meningkatkan kualitas, waktu respons, kustomisasi, dan harga. Meskipun persediaan layanan sering didasarkan pada informasi, tidak semua informasi persediaan memenuhi syarat sebagai layanan. Ini harus merupakan langkah-langkah pra-tindakan dalam proses pengiriman. Selanjutnya ia mengatakan bahwa Kinerja proses pelayanan tergantung pada tiga faktor: batas tarikulur, sumber daya dan kebijakan akses. Persediaan jasa perlu dilihat dalam konteks bagaimana perusahaan bersaing dan menciptakan nilai bagi pelanggan. Setiap jasa merupakan bundel dari atribut kualitas, kecepatan, kustomisasi dan harga yang dihasilkan melalui serangkaian proses. Adapun rancangan kerja untuk desain proses jasa tersebut secara lebih jelas dapat dilihat dalam gambar 7

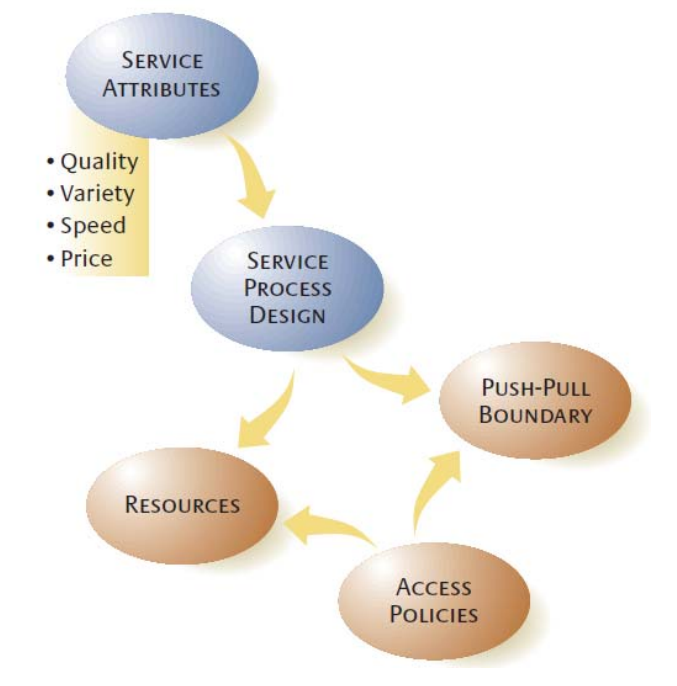

Gambar 7 Kerangka Kerja Disain Proses Jasa Sumber: Chopra and Lariviere (2005;61) 
Chopra and Lariviere (2005; 61) mengemukakan bahwa persediaan layanan dapat mempengaruhi kinerja pada atribut kompetitif kualitas, pembiasaan kecepatan, dan harga. Keinginan untuk meningkatkan dalam salah satu dari dimensi-dimensi ini dapat membenarkan investasi dalam persediaan layanan. Cara-cara dalam hal mana persediaan jasa dapat meningkatkan kinerja dan alasan untuk membangun persedian jasa adalah seperti terlihat dalam tabel 1 . Sebelum berinvestasi dalam persediaan jasa, penyedia jasa harus mempertimbangkan ketika persediaan jasa akan meningkatkan posisi kompetitif dan bagaimana kebijakan akses dapat disesuaikan untuk memaksimalkan peluang keberhasilan. Menentukan tingkat persediaan lokasi jasa yang ideal dari batas tarik-ulur tergantung pada karakteristik khusus dari pasar tertentu dan biaya menciptakan persediaan jasa.

Karakteristik pasar menentukan kemungkinan bahwa persediaan jasa akan benar-benar digunakan secara aktual; biaya mempengaruhi bagaimana hal tersebut berisiko untuk membangun persediaan jasa. Seperti persediaan produk, pembangunan persediaan jasa lebih menarik bila ada kemungkinan lebih besar bahwa hal itu benar-benar akan digunakan atau ketika biaya dari pembangunan persedian jasa itu rendah.

Salah satu karakteristik pasar yang mendukung tingkat persediaan layanan yang tinggi adalah ketika layanan disesuaikan dapat disampaikan melalui penerapan suatu proses yang bersifat umum. Mesin anjungan tunai mandiri, bank, swalayan check-in di bandara dan lembaga pelelangan adalah contoh yang baik; prosesnya adalah standar, tetapi rincian transaksi berbeda. Dalam setiap kasus, sebuah proses standar memungkinkan untuk membangun persediaan layanan.

Adapun atribut-atribut jasa, cara-cara bagaimana persedian jasa dapat memperbaiki kinerja organisasi dan alasan untuk membangun persedian jasa tersebut adalah seperti terlihat dalam tabel 1 berikut.

Tabel 1 How Service Inventory Improves Performance Along Service Attributes

\begin{tabular}{|c|c|c|}
\hline Service Attribute & $\begin{array}{l}\text { Ways in Which Service Inventory Can } \\
\text { Improve Performance }\end{array}$ & Reasons to Build Service Inventory \\
\hline Quality & $\begin{array}{l}\text { - Provides for consistency } \\
\text { - Facilitates service recovery }\end{array}$ & $\begin{array}{l}\text { Customers value transactional conformance } \\
\text { Enables simple, standardized response to common } \\
\text { service failures }\end{array}$ \\
\hline Speed & $\begin{array}{l}\text { - Reduces amount of work needed after } \\
\text { customer arrival } \\
\text { - Allows provider to expand capacity } \\
\text { - Reduces handoffs }\end{array}$ & $\begin{array}{l}\text { Allows for significant capacity expansion } \\
\text { Eliminates need for handoffs }\end{array}$ \\
\hline Customization & $\begin{array}{l}\text { - Applies standard process to individual } \\
\text { inputs } \\
\text { - Allows greater customer control }\end{array}$ & $\begin{array}{l}\text { Customers provide unique inputs to a standard } \\
\text { process } \\
\text { Customers value exercising greater control }\end{array}$ \\
\hline Price & $\begin{array}{l}\text { - Facilitates self-service } \\
\text { - Allows use of cheaper resources } \\
\text { - Enhances resource productivity }\end{array}$ & $\begin{array}{l}\text { Significantly reduces resource costs } \\
\text { Increases staff productivity } \\
\text { Allows higher resource utilization }\end{array}$ \\
\hline
\end{tabular}

Sumber: Chopra and Lariviere $(2005 ; 61)$ 


\section{HASIL DAN PEMBAHASAN}

Dalam bagian ini akan dibahas mengenai perbandingan antara objek yang dijadikan bahan pembahasan yaitu jasa pelayanan rumah sakit dengan literature yang telah dibahas. Seperti yang telah dibahas sebelumnya bahwa jasa memiliki karakteristik yang unik yang tidak sama dengan produk yang berupa barang. Demikian pula halnya dengan jasa rumah sakit disamping memiliki karakteristik yang unik juga orientasi organisasi atau lembaganya berbeda dengan lembaga bisnis pada umumnya. Jika merujuk pada pembagian jasa yang dikemukakan oleh Fitzsimmons (2011:5) maka pelayanan jasa pelayanan kesehatan rumah sakit adalah termasuk ke dalam Personal Service.

Jasa tidak berwujud (intangible) seperti produk fisik, yang menyebabkan pengguna jasa rumah sakit tidak dapat melihat, mencium, mendengar, dan merasakan hasilnya sebelum mereka mengkonsumsinya (menjadi subsistem lembaga rumah sakit). Untuk menekan ketidakpastian, pengguna jasa rumah sakit akan mencari tanda atau informasi tentang kualitas jasa tersebut. Tanda maupun informasi dapat diperoleh atas dasar letak lokasi lembaga rumah sakit, lembaga penyelenggara, peralatan dan alat komunikasi yang digunakan, serta besarnya biaya yang ditetapkan. Beberapa hal yang akan dilakukan lembaga pendidikan untuk meningkatkan calon pengguna jasa pendidikan adalah: (1) meningkatkan visualisasi jasa yang tidak berwujud menjadi berwujud; (2) menekankan pada manfaat yang akan diperoleh; (3) menciptakan atau membangun suatu nama merek lembaga rumah sakit (hospital brand name); (4) memakai nama seeorang yang sudah dikenal untuk meningkatkan kepercayaan konsumen.

Jasa pelayanan medis tidak dapat dipisahkan (perishability) dari sumber penyedia jasa itu sendiri, yaitu lembaga rumah sakit yang menyediakan jasa tersebut. Artinya, jasa pelayanan kesehatan/medis dihasilkan dan dikonsumsi secara serempak (simultan) pada waktu yang sama. Jika seorang pasien rumah sakit membeli jasa maka akan berhadapan langsung dengan penyedia jasa medis. Dengan demikian, jasa lebih diutamakan penjualannya secara langsung dengan skala operasi yang terbatas. Oleh karena itu, lembaga rumah sakit dapat menggunakan strategi bekerja dalam kelompok yang lebih besar, bekerja lebih cepat, atau melatih para penyaji jasa agar mereka mampu membina kepercayaan pelanggannya.

Bervariasi (heterogenity); jasa bersifat sangat beragam karena merupakan nonstandardized out-put, artinya banyak variasi bentuk, kualitas dan jenis, tergantung pada siapa, kapan, dan di mana jasa tersebut dihasilkan. Demikian pula halnya dengan pelayanan kesehatan rumah sakit, meskipun terdapat pedoman yang berupa peraturan, tata tertib, SOP, dalam pelasanaannya tidak ada yang standar. Berbeda tenaga medis sudah tentu berbeda cara dan gaya penyampaian. Situasi dan kondisi juga sangat memengaruhi metode dan kualitas pelayanan medis.

Simultanitas (simultaneity); jasa diciptakan dan dikonsumsi secara bersamaan. Demikian halnya dengan jasa pelayaan kesehatan sebuah rumah sakit, dimana proses produksi jasa pendidikan dan prosess konsumsi jasa pendidikan tersebut dilakukan secara bersamaan. Jika penyedia jasa seperti dokter atau perawat berhalangan hadir, secara otomatis tidak bisa jasa pelayanan dokter atau perawat tersebut dikonsumsi oleh pasien. 


\section{PENUTUP}

Pada dasarnya persedian tidak boleh lebih dan tidak boleh kurang, lebih merupakan biaya dan kurang juga adalah biaya. Jadi manajemen persediaan pada dasarnya terletak pada cara mengelola persediaan pada tingkat yang optimal. Teori-teori manajemen persedian jasa pada dasarnya sama dengan teori-teori manajemen persedian (inventory) untuk produk yang berupa barang. Teori-teori persediaan umumnya mengacu pada tiga pertanyaan utama yaitu: jumlah barang yang harus dipesan, waktu harus melakukan pemesanan, dan jumlah persediaan yang harus dipertahankan. Ketiga pertanyaan tersebut dijawab dengan teori klasik tentang model persediaan yang ekonomis (economic order quantity), titik pemesanan kembali (reorder point), dan persedian pengaman (safety stock).

Mengingat model-model EOQ dalam praktik hampir mustahil dilakukan (karena mengandung asumsi-asumsi yang sulit dipenuhi), sebaiknya lebih diarahkan dan diperbanyak lagi rencana-rencana penelitian selanjutnya yang hasilnya bisa diterapkan dalam praktik bisnis. Disamping itu juga modelmodel persedian untuk jasa belum ada yang spesifik, tetapi secara garis hampir sama dengan model persediaan untuk produk yang berupa barang. Padahal seperti kita ketahui jasa memiliki sifat-sifat tertentu yang unik dan berbeda jauh dengan produk barang. Mengingat sektor jasa merupakan sektor yang paling besar memberikan kontribusi pada pendapatan suatu negara, maka perlu perhatian lebih untuk aspek tersebut. Jasa pelayanan kesehatan merupakan salah satu sektor jasa yang turut memberikan kontribusi bagi sektor jasa secara keseluruhan. Rumah sakit merupakan salah satu lembaga penyedia jasa pelayaanan kesehatan tersebut. Dalam kegiatan operasionalnya sebuah rumah sakit memerlukan bahan, barang, tempat dan perlengkapan lainnya yang sangat beragam dan kompleks. Menurut bidang pemanfaatannya bahan dan barang yang harus disediakan di rumah sakit dapat dikelompokkan menjadi: Logistik Obat, Logistik Alat Kesehatan, Logistik Food and Baverages, Logistik Bahan Habis Pakai, Logistik Barang Kuasi, Logistik Peralatan Medis dan Non Medis, Logistik Sarana dan Prasarana Gedung dan Logistik Linen

\section{DAFTAR PUSTAKA}

Cheng, F., Ettl, M., Lin, Grace, Yao, D. D. (2002). Inventory-service optimization in configure-toorder systems. Manufacturing \& Service Operations Management; Spring 2002; 4, 2; ABI/INFORM Complete, p144

Chopra, S., and. Lariviere, M. A. (2005). Managing Service Inventory to Improve Performance. MITS loan management Review, Vol 47, No1.

Fitzsimmons, J. A., Fitzsimmons, M. J., (2011), Service Inventory, Operations, Stratergy, Information technology. Mc Graw Hill International.

Heizer, J., Render, B. (2011). Operations Management. 10th Edition. Pearson Education.

Katok, E., Thomas, D., \& Davis, A. (2008). Inventory Service-Level Agreements as Coordination mechanism. Manufacturing and Service Operation Management, Vol 10, No 4, pp 609-624.

Stevenson, W. J. (2009). Operations Management. $10^{\text {th }}$ Edition. Mcgraw-hill/Irwin. 